\title{
Introduction
}

In the mid-twentieth century, thousands of women moved from diverse communities across central Africa to new towns in an area historically associated with Lamba, Lunda and other societies, some of whom had produced valuable minerals there. These women, many joined by their husbands and families, engaged in a wide range of economic activities including subsistence and commercial farming but also informal trade and labour. Over the next decades - as their number swelled to tens and then hundreds of thousands - they built vibrant communities based on new forms of social, cultural and religious association and identities. They and their families had, however, to contend with repression and attempts at political domination by illegitimate authorities over which they lacked control, severe market fluctuations in the buying power of their customers and the environmental effects of their neighbours' activities on their health, land and economic opportunities.

This is a history of the Central African Copperbelt that is every bit as representative as one that is far better known. The dominant history of the Copperbelt region, encompassing the mining towns of HautKatanga (in today's Democratic Republic of Congo - DRC) and neighbouring Zambia, is of male migration for wage labour - first temporary and later permanent - to new industrial mines run by Western companies, intimately connected to the colonies that drew their borders, ruled them and enabled the exploitation of their mineral wealth. Male migrants, this history tells us, brought their families to new company towns, where they founded ethnic associations, political parties and trade unions, and where they secured improved living conditions, funded by the revenue generated by expanding production of copper and later cobalt. With national independence came mine nationalisation, but this was followed by economic decline commensurate with falling mineral prices and the late twentieth century saw corrupt privatisation processes and (in the DRC) military conflict that accelerated the collapse of these communities. 
The latter history dominates our imagination of the Copperbelt for a number of reasons, some obvious, some less so. The region mattered for global capital and policy-makers insofar as it produced strategic minerals: copper that enabled the global post-Word War Two boom and modern warfare, supplying the uranium used on Hiroshima and Nagasaki. It came to the attention of company and colonial officials (and their post-colonial successors) when its residents rioted, struck work and organised politically, disrupting the flow of minerals and threatening their control over it. For social scientists, some of whom were funded by and some of whom were critical of these mine companies and states, this version of the Copperbelt provided revealing evidence of social change enabled by new urban contexts, change that needed careful management and specific policy interventions. ${ }^{1}$ Later, the Copperbelt provided a cautionary tale of skewed development, unsustainable consumption and over-dependence on a wasting resource. $^{2}$ By the 1980 s this inspiring hyper-modern space had become a dinosaur, in need of external aid and reform: social scientists now explained the failure of Copperbelt modernity and charted its residents' efforts to challenge or to manage their decline, as well as their nostalgia for its better times. ${ }^{3}$

1 Among the many important early studies in this area, see: Jean-Luc Vellut, 'Les Bassins Miniers de L'Ancien Congo Belge'. Essai D’Histoire Économique et Sociale (1900-1960)', Les Cahiers du CEDAF (Brussels: CEDAF, 1981); Charles Perrings, Black Mineworkers in Central Africa: Industrial Strategies and the Evolution of an African Proletariat in the Copperbelt, 1911-1941

(New York: Africana Publishing, 1979); Arnold L. Epstein, Politics in an Urban African Community (Manchester, UK: Manchester University Press, 1958); J. Clyde Mitchell, 'The Kalela Dance: Aspects of Social Relationships Among Urban Africans in Northern Rhodesia', Rhodes Livingstone Institute Papers No. 29 (Manchester, UK: Manchester University Press, 1959); Pierre Caprasse, Leaders Africains en Milieu Urbain (Brussels: CEPSI, 1959); Arthur Doucy and Pierre Feldheim, Problèmes du Travail et Politique Sociale an Congo Belge (Brussels: Editions de la Librairie Encyclopédique, 1952).

2 Robert H. Bates, Unions, Parties and Political Development: A Study of Mineworkers in Zambia (New Haven, CT: Yale University Press, 1971); Philip Daniel, Africanisation, Nationalisation and Inequality (Cambridge: Cambridge University Press, 1979).

3 James Ferguson, Expectations of Modernity: Myths and Meanings of Urban Life on the Zambian Copperbelt (Berkeley: University of California Press, 1999); Donatien Dibwe dia Mwembu, Bana Shaba Abandonnés par Leur Père: Structures de L'Autorité et Histoire Sociale de la Famille Ouvrière an Katanga, 1910-1997 (Paris: L'Harmattan, 2001); Benjamin Rubbers, Le Paternalisme en Question: Les Anciens Ouvriers de la Gécamines face à la lIbéralisation du 
If these external characterisations were the only reason for the hegemony of this one-sided vision of Copperbelt society and the marginalisation of the historical experiences highlighted in the opening paragraph, then the primary task of this study would be to displace them by a sustained consideration of Copperbelt stories that have not been told, adding to the historical record the 'hidden' or 'invisible' histories of, among other things, women's work, informal communities, farming and the despoliation of land by pollution. And this book does do this by extending the social history of the Central African Copperbelt to these and other topics that have not been the sustained focus of scholarly and institutional attention, of what is termed here official or elite 'knowledge production'.

And yet the dominant history of the Copperbelt, of men and mining, of politics and economics, of boom and bust, modernity and its fall, is also the history that has been narrated and told, in the past and today, by Copperbelt residents both to social scientists and to each other. The mythic modernist narrative identified and eloquently critiqued by James Ferguson two decades ago is one that, despite its evident distortion of the complex, open-ended realities of recent Copperbelt history, underwrites the dominant political, social and cultural discourses of the region. ${ }^{4}$ The simplistic, distorting, modernist narrative of a binary transition from rural village life - supposedly traditional, static, superstitious, communal and reciprocal - to the modern, materialistic, capitalist, individualist and Christian town - while now happily rejected by post-modern, postcolonial social science, has underpinned the aspirations of politicians, the demands of protestors and the songs and paintings of Copperbelt musicians and artists and, in an era of sustained decline, still does so today.

This is then the dominant history of the region both because of the distorting and silencing effects of intellectual knowledge production (with its Western gaze, colonial archive, white researchers and male subjects) and because Copperbelt communities have produced their own knowledge that, while differing from the binaries of 'tradition/ modernity' in subtle and important ways, nonetheless largely

Secteur Minier Katangais (RD Congo) (Paris: L'Harmattan, 2013); Patience Mususa, 'There used to be order: life on the Copperbelt after the privatisation of the Zambia Consolidated Copper Mines', unpublished PhD thesis, University of Cape Town (2014).

4 Ferguson, Expectations of Modernity. 
articulates its own modernist narrative from below. This book will, therefore, in presenting an intertwined history of Copperbelt society and the production of knowledge about that society from within and without, attempt to explain the relationship between the two. It argues that, from the start, popular and elite ideas about the region have been intimately interconnected and mutually constitutive, even if profoundly unequal in their reach and influence. African communities, which provided policy-makers and social scientists with the raw material for their understanding and articulations of historical and social change, had their own diverse ideas about and claims for social advancement that they articulated in forms that resonated with those with power over them and who they sought to influence. The language of urban social change - of civilisation, citizenship, status and development - infused the individual and collective self-expression of Copperbelt communities and informed the ways they explained the relationship between past, present and hoped-for future.

The fact that the Copperbelt is such an intensively studied region is both a reason for this study and the underlying basis of it. Readers are, however, entitled to ask what they can possibly learn about the Central African Copperbelt that they don't already know. The book's claim to innovation and originality rests on the following three interlinked approaches.

\section{Historicising the Cross-Border Copperbelt}

Despite the many common factors linking - as well as important differences between - the Zambian and Congolese Copperbelt regions, they have, with very few exceptions, been studied separately: their presence in their respective colonies (Northern Rhodesia and Belgian Congo) and nation-states has been taken for granted by a methodological nationalism that assumes their relationship to these states and downplays or ignores their parallel developments and, more importantly, the extent to which this has been a single region, linked by flows of people, minerals, goods and ideas, divided by a (post)colonial border that has then itself acquired a range of meanings and values for its resident communities. ${ }^{5}$

5 For a characteristically insightful engagement with the cross-Copperbelt region, see Luise White, Speaking with Vampires: Rumor and History in Colonial Africa (Berkeley: University of California Press, 2000), pp. 269-306. 
This study aims to both holistically analyse the Copperbelt region and to compare its two component parts, drawing out their similarities and divergences and the way these have been shaped by the interaction of material differences and the way those differences have been imagined and given meaning. These date back to the early (pre-colonial) exploitation of the region's mineral wealth, when it provided a significant basis for the growth of important Luba and Lunda kingdoms in what is today the DRC. Whereas in Katanga prominent outcrops provided access to significant copper ore, to the south most copper sulphide ores lay deeper underground and could not be mined effectively without industrial technology. This led to a vital difference in the way that copper mining is imagined: whereas in Zambia copper is largely associated with externally imposed industrial-scale mining and migrant labour, in Katanga the historical memory of indigenous pre-colonial mining partly shaped the late-colonial political discourse of its secession and the ethnicisation of Katangese politics.

The early development of Copperbelt industrial mining was, however, deeply interlinked by the overlapping capital formations of three principal mining companies and their parallel prospecting initiatives. The early development of Katangese mines was likewise enabled by the recruitment of labour from Northern Rhodesia's Northern Province, primarily Bemba and neighbouring populations that would later form the largest part of the labour force of Northern Rhodesia's own mine industry as it developed from the late 1920s. ${ }^{6}$ Labour recruitment, a general problem in a region of sparse population, was addressed (as across southern Africa) by recruitment agencies but - from the early 1920 s - in divergent ways. The suppression of the 1919 white workers' strike in Katanga led the mine company Union Minière du HautKatanga (UMHK) and the Belgian state to encourage 'nationalist' recruitment: a smaller number of Europeans from Belgium itself and an emphasis on attracting African migrants from Belgian Congo and Ruanda-Urundi. ${ }^{7}$ During the 1920 s and 1930s UMHK invested in mechanisation and labour stabilisation, skilling its African workers and extending their contracts but also encouraging them to bring

6 Enid Guene, 'Copper's Corollaries: Trade and Labour Migration in the Copperbelt (1910-1940)', Zambia Social Science Journal, 4, 1 (2013).

7 John Higginson, A Working-Class in the Making: Belgian Colonial Labor Policy, Private Enterprise, and the African Mineworker, 1907-1951 (Madison:

University of Wisconsin Press, 1989), pp. 61-112. 
their families to settle in Katanga's mining camps. South of the border, in accordance with southern African racial thinking, recruits to the mines of the Anglo-American Corporation (AAC) and Rhodesian Selection Trust (RST) were treated as temporary migrants with no rights in town until the 1940s. While the number of European workers in Katanga was effectively contained, white labour in Northern Rhodesian mines steadily increased in the inter-war period: this divergence resulted partly from the more basic nature of (mostly) open pit mining north of the border, while to the south (mainly) underground mining required greater technical skills. There, the European Mineworkers' Union (MWU) secured an agreement that barred Africans from jobs currently held by Europeans. By 1945, while UMHK employed 1,100 European mineworkers in the most senior roles, there were in 1956 still c.7,000 whites employed in Northern Rhodesian mines: as a result of a 'colour bar', Africans were less able to advance to more senior roles. ${ }^{8}$

In the mid-twentieth century, rapid social and economic change in sub-Saharan Africa ignited interlinked debates regarding the impact of colonial rule, education, urbanisation and migration on African ideas, identity and associational life. ${ }^{9}$ Africans developed new ideas and organisations - sometimes under European paternalistic guidance and sometimes expressly against their direction - to defend themselves from violence and exploitation, claim a place within the colonial and capitalist order and challenge (partially or entirely) its legitimacy on moral, legal, cultural and political grounds. ${ }^{10}$ On the Copperbelt this took

8 Perrings, Black Mineworkers in Central Africa, pp. 117-29.

9 It is clearly impossible to provide a satisfactory account here of relevant literature on these vast topics. For the nature of colonialism see A. Adu Boahen, African Perspectives on European Colonialism (Baltimore, MD: Johns Hopkins University Press, 2011); Martin Chanock, Law, Customs and Social Order: The Colonial Experience in Malawi and Zambia (Cambridge: Cambridge University Press, 1985); and Crawford Young, The African Colonial State in Comparative Perspective (New Haven, CT: Yale University Press, 1994).

10 For foundational work in this area see Thomas Hodgkin, Nationalism in Tropical Africa (London: Frederick Mueller, 1956) and James S. Coleman, Nationalism and Development in Africa: Selected Essays (Berkeley: University of California Press, 1994). For social and political organisation in colonial Northern Rhodesia, see Robert I. Rotberg, The Rise of Nationalism in Central Africa: The Making of Malawi and Zambia, 1873-1964 (Cambridge, MA: Harvard University Press, 1967) and, more recently, Jan-Bart Gewald, Marja Hinfelaar and Giacomo Macola (eds.), Living the End of Empire: Politics and Society in Late Colonial Zambia (Leiden: Brill, 2011). For the DRC see 
a specific form that reflected its experience of urban migration and focussed on - but was not limited to - wage labour in the mining industry and the communities associated with them. From the 1940s, Bemba political leadership became prominent in Northern Rhodesian mining towns and Bemba-speaking mineworkers would play a leading role in union organisation and in Zambian nationalism in the 1950s. In a similar vein, Kasai Baluba migrants flocked to work in the Katangese mines and were stereotyped, like the Bemba, as culturally receptive to 'modern' wage labour by state officials and, in particular, Catholic missionaries, who played a far greater role in shaping UMHK social policy than their mission counterparts in Northern Rhodesia. ${ }^{11}$

The growing (though unequal) literacy and educational opportunities available to some Copperbelt residents certainly generated an increasingly vibrant intellectual life that can be usefully compared with the 'public spheres' of west and east Africa, analysed to such powerful effect by, in particular, Karin Barber, Stephanie Newell and Emma Hunter. ${ }^{12}$ Mission-educated Africans, like their counterparts elsewhere, used new cultural and political associations to establish a fragile place for

René Lemarchand, Political Awakening in the Congo (Berkeley: University of California Press, 1964) and Georges Nzongola-Ntajala, The Congo from Leopold to Kabila: A People's History (London: Zed Books, 2002). For the role of labour unions in colonial Africa, see Frederick Cooper, Decolonization and African Society: The Labor Question in French and British Africa (Cambridge: Cambridge University Press, 1996).

11 Key works in the literature on colonial ethnic identification include Terence O. Ranger, 'The Invention of Tradition in Colonial Africa', in Eric Hobsbawm and Terence Ranger, The Invention of Tradition (Cambridge: Cambridge University Press, 1983), pp. 211-63; Leroy Vail (ed.), The Creation of Tribalism in Southern Africa (Oxford: James Currey, 1989), particularly the chapters by Bogumil Jewsiewicki (on the Congo) and Brian Siegel (on the Lamba); Thomas Spear, 'Neo-Traditionalism and the Limits of Invention in British Colonial Africa', Journal of African History, 44, 1 (2003), pp. 3-27; and Terence O. Ranger, 'The Invention of Tradition Revisited: The Case of Colonial Africa', in Terence O. Ranger and Olufemi Vaughan (eds.), Legitimacy and the State in Twentieth Century Africa. Essays in Honour of A. M. H. KirkGreene (London: Palgrave Macmillan, 1993), pp. 62-111.

12 Karin Barber, Print Culture and the First Yoruba Novel: I. B. Thomas's 'Life Story of Me, Segilola' and Other Texts (Leiden: Brill, 2012); Stephanie Newell, Literary Culture in Colonial Ghana: 'How to Play the Game of Life' (Bloomington: Indiana University Press, 2002) and 'Articulating Empire: Newspaper Readerships in Colonial West Africa', New Formations, 73 (2011), pp. 26-42; and Emma Hunter, Political Thought and the Public Sphere in Tanzania: Freedom, Democracy and Citizenship in the Era of Decolonization (Cambridge: Cambridge University Press, 2015). 
themselves within the late colonial order, reflecting on their changing identity and what it meant to be both African and modern in a context in which the attributes of 'modernity' were characterised as inherently Western. By the late 1940s and 1950s a literate Copperbelt public, mission-educated and politically active, was organising in Katanga's cercles and Northern Rhodesia's welfare associations (see Chapter 4) and articulating their views about social change in new periodicals, most still run by European publishers or the mine companies themselves, which are discussed in Chapter $5 .^{13}$

Meanwhile, a steady expansion in the social services provided to mineworkers' families in the UMHK 'camps', including early childcare and housing for larger families, was predicated on the notion that the modern nuclear family would provide the ideal domestic environment for productive and apolitical workers. ${ }^{14}$ The threat of radicalisation, symbolised in the 1941 mineworkers' strike, was equally countered by an authoritarian system of surveillance and propaganda. In Northern Rhodesia meanwhile, a similar strike in 1940 was taken as a sign that 'migrant' Africans needed urban settlement and modern political associations, leading to post-World War Two British sponsorship of African trade unionism. ${ }^{15}$

As can be seen, similar historical dynamics and material circumstances were imagined, both by Copperbelt residents and those who ruled them, in both similar and distinctive ways, leading to interventions and ideas that fed back into these societies and further shaped their development. Two broad ideas of Copperbelt society - presented here in a necessarily simplified way and elaborated on further throughout this book - would, as a result, develop on either side of the border. In Haut-Katanga, the early and sustained intervention of

13 A particularly important study is provided by Deborah Kallmann, 'Projected Moralities, Engaged Anxieties: Northern Rhodesia's Reading Publics, 1953-1964', International Journal of African Historical Studies, 32, 1 (1999), pp. 71-117.

14 Donatien Dibwe dia Mwembu, Histoire des Conditions de Vie des Travailleurs de L'Union Minière du Haut-Katanga/Gécamines (1910-1999) (Lubumbashi: Presses Universitaire de Lubumbashi, 2001). The term 'camp' continued to be used long after these areas had become permanent areas of their respective towns and cities, but was ultimately replaced by 'cité'.

15 Helmuth Heisler, 'The Creation of a Stabilized Urban Society: A Turning Point in the Development of Northern Rhodesia/Zambia', African Affairs, 70, 279 (1971), pp. 125-45. 
UMHK in shaping this new urban society was to some extent successful: generations of residents of mine cités have internalised and reproduced iterations of the idea that the company, UMHK and its successor Gécamines, was the 'mother and father' of their workers and their families. This patrimonial loyalty nonetheless enabled those residents to make specific, limited claims on the company and other actors. ${ }^{16}$ The suppression of implicitly redistributive political association - indeed, of any meaningful independent organisation outside company and state control - led, as elsewhere in the Belgian Congo, to the dominance of ethnicity as the framework of political aspiration, influencing the ethnic violence of the early 1960s and early 1990s that resulted from effective elite manipulation of these identities. In Northern Rhodesia, in contrast, the provision - by the mid-1950s - of a broadly comparable system of social welfare was perceived to be the result not of company generosity but instead of industrial combination and action by mineworkers and their families. The marginalisation of the indigenous Lamba population, and the relative unimportance of historical memory of pre-colonial mining societies, meant the absence of the building blocks necessary for the construction of a 'Copperbelt' ethno-nationalism rooted in autochthonous claims. The continued colour bar, and the white supremacist threat posed by the Central African Federation (CAF) which in 1953 unified Northern Rhodesia with Nyasaland and settler-controlled Southern Rhodesia, accelerated the development of a multi-ethnic African nationalism in which the Copperbelt's residents and their labour organisations played a central role. ${ }^{17}$ This self-consciously cosmopolitan materialist identity has been central to Zambian Copperbelt political culture ever since.

These very different ideas of Copperbelt society would not, however, have taken the form they did if it had not been for the central role played in their articulation, documentation and crystallisation by those who studied and disseminated knowledge about these places.

16 Dibwe dia Mwembu, Histoires des Conditions, p. 58; R. Brion and J.-

L. Moreau, De la Mine à Mars: La génèse d'Umicore (Tielt: Lanoo, 2006), pp. 273-5.

17 Miles Larmer, Rethinking African Politics: A History of Opposition in Zambia (Farnham: Ashgate, 2010), pp. 27-34. 


\section{Comparative Knowledge Production in the Belgian and Anglophone Academies}

In the early colonial period, the 'fact' that all Africans lived in 'tribes' was a central assumption in much European colonial policy-making, particularly that of Britain and Belgium. The classification and documentation by colonial officials, missionaries and ethnographers of 'tribal' cultures, languages, laws and structures across much of the continent constituted a massive exercise in knowledge production, a process that helped fix and give socio-political meaning to identities that were hitherto more contested and subject to continuous historical change. Such identities, despite recognition of their 'constructed' nature, continue to be central to political contestation and affiliation in post-independence Africa to the present day. ${ }^{18}$ As has been increasingly recognised, a vital role in the construction of these identities was played by African intermediaries - chiefs, their councillors, translators and other middle-men - who for various reasons supplied Europeans with the raw historical and cultural material that enabled them to distinguish one 'tribe' from another. ${ }^{19}$

This process of tribal documentation can be usefully compared with the social scientific analysis of late colonial Copperbelt society between the late 1940s and the early 1960s. As already indicated, the Central African Copperbelt has been central to academic analysis of modern urban historical change in Africa. Copper production, driven by global demand and enabled by European imperialism, transformed market relations and brought, social scientists agreed, modern industry to an African interior otherwise isolated from progressive historical change. The African mineworkers recruited to produce that copper likewise provided an ideal type of nascent working-class identity. A new urban society was understood to be developing in its new towns, producing in turn a modern social and political consciousness. Political nationalism and economic nationalisation of strategic mining resources were equally seen as flowing directly or indirectly from mining-led

18 See, for example, Mahmood Mamdani, Citizen and Subject: Contemporary Africa and the Legacy of Late Colonialism (Princeton, NJ: Princeton University Press, 1996); Gabrielle Lynch, I Say to You: Ethnic Politics and the Kalenjin in Kenya (Chicago, IL: Chicago University Press, 2011).

19 Benjamin Lawrance, Emily L. Osborn and Richard L. Roberts (eds.), Intermediaries, Interpreters, and Clerks: African Employees in the Making of Colonial Africa (Madison: University of Wisconsin Press, 2006). 
development. Socialist-oriented academics looked to the incipient African working class to develop into a vanguard of radical progressive change and, when this apparently did not occur, sought to explain this 'failure' in ways that characterised African workers as divergent from an implicit or explicit norm of class consciousness. ${ }^{20}$

Social scientists on both sides of the border identified parallel problems associated with industrialisation and urbanisation, but came to markedly different conclusions regarding the capacity of Africans to manage their own transition to these new urban identities. In challenging racialised notions south of the border, Rhodes-Livingstone Institute (RLI) scholars such as Epstein and Clyde Mitchell asserted the adaptability of Africans to modern town life. ${ }^{21}$ Less well known, at least in Anglophone circles, is the parallel process of colonial knowledge production in the Belgian academy. ${ }^{22}$ The Centre d'Etudes des Problèmes Sociaux Indigènes (CEPSI) was established in 1946 by liberal Catholic academics who were critical of settler colonialism. Working with major companies, particularly UMHK, CEPSI researchers focussed on absenteeism and poor labour productivity, which they associated with Africans' difficulties in coming to terms with the demands of modern life in urban centres of extra-coutumier ('non-customary') existence. ${ }^{23}$ Work by CEPSI and RLI researchers, although reaching contrasting conclusions, was decisively shaped by the political context of the late colonial period in which modernisation theory assumed that historical or developmental progress in nonWestern societies would follow the same path from largely rural agricultural societies to urbanised industrialised ones as that supposedly

20 Giovanni Arrighi and John S. Saul (eds.), Essays on the Political Economy of Africa (New York: Monthly Review Press, 1973). For subsequent discussion of the labour aristocracy thesis in Africa, see Richard Sandbrook and Robin Cohen (eds.), Development of an African Working-Class (London: Longman, 1975). For its application to central Africa, see Jane L. Parpart, 'The Labour Aristocracy in Africa: The Copperbelt Case 1924-1967', African Economic History, 13 (1984), pp. 171-91.

21 Epstein, Politics in an Urban African Community; J. Clyde Mitchell, Cities, Society and Social Perception: A Central African Perspective (Oxford: Clarendon Press, 1987).

22 Marc Poncelet, L'Invention des Sciences Coloniales Belges (Paris: Karthala, 2008); Benjamin Rubbers and Marc Poncelet, 'Sociologie Coloniale au Congo Belge: Les Études sur le Katanga Industriel et Urbain à la Veille de L'Indépendance', Genèses, 2, 99 (2015), pp. 93-112.

23 Rubbers and Poncelet, 'Sociologie Coloniale au Congo Belge', pp. 95-7. 
taken by Western countries in the eighteenth and nineteenth centuries. ${ }^{24}$ In practice, the Copperbelt region developed, as we will see, in highly uneven ways, far from the confident imaginings of some social scientists or the racialised nightmares of others: mineworkers did not surrender ties to rural areas of origin; extractive mining did not stimulate wholesale industrial development; and tens of thousands of migrants scratched out a precarious living in 'squatter' areas. People, goods, wealth and culture continued to flow between villages and mining towns, creating unstable hybrid cultures that combined reconstructed ethnic identities with displays of self-consciously 'modern' materialism. Nonetheless, as social scientific research about Copperbelt societies developed in significant new ways over the coming decades, it continued to be shaped, as Ferguson has shown, by these influential but ultimately distorted notions of urban modernity. ${ }^{25}$

This is not, however, to argue that there have not been important developments in the social scientific and historical understanding of the region since the influential heyday of RLI-CEPSI research. Indeed, as the structure of this book indicates, new ideas and approaches that developed and/or became influential in the academy were continually applied to each new iteration of Copperbelt research in the context of the region's political independence, reflecting both global and local social, economic and political changes and, equally, innovations and trends in the intellectual outlook and methodological approaches of those who sought to understand them. For example, Marxistinfluenced researchers sought in the 1970s to identify a late-colonial 'working class in the making' and then tried to explain why one of Africa's most proletarian societies did not subsequently develop a fully fledged class consciousness (Chapters 2 and 4). Development economists meanwhile blamed the region's economic problems on an 'urban bias' created by politically influential Copperbelt wage-earners and consumers (Chapters 6 and 8). Feminist-influenced researchers identified the prominent role of women in Copperbelt labour and

24 For 'take-off' theories of development see Walt W. Rostow, The Stages of Economic Growth: A Non-Communist Manifesto (Cambridge: Cambridge University Press, 1960). The leading critic of such 'high modernist' developmentalist thought is James S. Scott: Seeing Like a State: How Certain Schemes to Improve the Human Condition Have Failed (New Haven, CT: Yale University Press, 1999).

25 Ferguson, Expectations of Modernity. 
political movements and revealed the gender dynamics underlying both company policies and societal change (Chapter 5). The rich cultural output of Haut-Katanga's towns was examined during the 1970s and 1980s, with visual art, theatre and music providing insights into the articulation of social identity (Chapter 7). The severe and sustained downturn of the 1980s onwards brought a new set of interventions to the region, as donors and international finance institutions (IFIs) sought to 'adjust' Copperbelt modernity to its new economic realities, but also made researchers suddenly aware of the region's profoundly uneven urbanisation (Chapter 8): Ferguson's own research, conducted in the midst of this downturn, should be understood in this context. One of those coping mechanisms, a supposed turn to urban farming, was in fact central to Copperbelt society from the start, its belated 'discovery' demonstrating the extent to which its actual development has been continually misunderstood by those who (re)searched for their generation's version of African urban modernity (Chapter 9). In historicising the long sweep of Copperbelt research over the past fifty years, the aim here is at least partly to assess the accuracy or otherwise of its analysis and the extent to which it deviates from social reality. In doing so, however, the study's central aim is to identify how social scientific research has characterised the Copperbelt in both enduring and changing ways, and to show how specific characterisations have been influenced by, among other things, the inheritance of the foundational texts of urban modernism, successive trends and emphases in both international and national policy and academic praxis, and the ideas and practices of Copperbelt societies themselves.

In analysing intellectual output about the region, this volume also analyses how the two parts of the Copperbelt have themselves been compared with each other and for what purpose: what role did this comparison play and to what purpose were those conclusions put? An influential body of global intellectual history has demonstrated the ways in which the colonial state was constituted through interimperial processes in which academic and colonial experts met in forums such as the International Colonial Institute (ICI), which from its establishment in 1892 enabled the dissemination of knowledge about techniques of empire across imperial boundaries. ${ }^{26}$ Although

26 Benoit Daviron, 'Mobilizing Labour in African Agriculture: The Role of the International Colonial Institute in the Elaboration of a Standard of Colonial 
such inter-imperial comparative processes can be found in many phases of European imperialism, the 'late colonial state', under pressure from nationalist movements and international critics to justify its existence, was particularly invested in developmental initiatives rooted in 'scientific' knowledge production and international co-operation within the emerging United Nations framework. ${ }^{27}$ Miguel Bandeira Jerónimo has, for example, shown how Portuguese imperialist officials sought knowledge, respectability and justification for their activities via participation in structures such as the International Labour Organisation (ILO). ${ }^{28}$ Belgian colonial practice in the inter-war and post-World War Two periods equally engaged with such interimperial and international processes, while British officials gathered regularly to compare their understanding of common problems in what was increasingly understood as a rapidly changing colonial reality. ${ }^{29}$ At inter-African conferences in the 1950s and 1960s organised by the Combined Commission for Technical Cooperation in Africa South of the Sahara (CCTA), French, Belgian, British, Portuguese, Rhodesian and South African officials assembled to address the problems of managing African labour: ${ }^{30}$ it is not coincidental that two of these events took place in Elisabethville (1950) and Lusaka (1957), since both Haut-Katanga and the Northern Rhodesian Copperbelt towns were key examples of labour challenges that could provide comparable

Administration, 1895-1930', Journal of Global History, 5, 3 (2010), pp. 479-501.

27 Crawford Young, The African Colonial State in Comparative Perspective (New Haven, CT: Yale University Press, 1994); John Darwin, 'What Was The Late Colonial State?', Itinerario, 23, 3-4 (1999), pp. 73-82; Frederick Cooper and Randall M. Packard (eds.), International Development and the Social Sciences: Essays on the History and Politics of Knowledge (Berkeley: University of California Press, 1998).

Miguel Bandeira Jerónimo and José Pedro Monteiro, 'Internationalism and the Labours of the Portuguese Colonial Empire', Portuguese Studies, 29, 2 (2013), pp. 142-63. See also the special issue of the Journal of Imperial and Commonwealth History 48, 5 (2020) on 'Imperialism, Globalization and (Inter)Colonial Encounters in Africa’, edited by Miguel Bandeira Jerónimo and Damiano Matasci.

29 Eva M. Schalbroek, 'The Commission for the Protection of the Natives and Belgian colonialism in the Congo (1908-1957)', unpublished DPhil thesis, University of Cambridge (2019); Anon, 'Report on the Conference on Urban Problems in East and Central Africa held at dola, Northern Rhodesia, in February, 1958', Journal of African Administration, 10, 4 (1959), pp. 182-252.

30 Isebill V. Gruhn, 'The Commission for Technical Co-Operation in Africa, 1950-65', Journal of Modern African Studies, 9, 3 (1971), pp. 459-69. 
lessons. Researchers from CEPSI and RLI were active and influential participants in such conferences and UMHK's interventionist policies in particular provided a supposedly ideal case of 'social engineering. ${ }^{31}$ Its pioneering stabilisation and community development programmes were admired by Northern Rhodesian officials as a model to follow and learn from, but one that, they felt, could not be implemented in their own mines where organised African mineworkers, 'tainted' by the negative influences of white mineworkers and the consumer economy, would challenge every aspect of its implementation (see Chapter 3). As would often prove the case, the comparison between the two regions served to emphasise their differences rather than identify their evident similarities and linkages.

In academic knowledge production too, the need to understand the Copperbelt as a single region enabling comparative analysis was widely advocated but rarely practised. The work of Charles Perrings is a noteworthy exception to the rule, with virtually all studies accepting rather than challenging the cartographic assertion of colonial and national borders. ${ }^{32}$ Researchers from RLI and CEPSI, while meeting periodically on the inter-imperial stage, remained largely rooted in their metropolitan and/or linguistic political and academic milieux and did little to consider the extent to which the people they studied lived across the border region. Subsequent generations of researchers have equally operated under the shadow of methodological nationalism, producing enlightening work on one or more 'Copperbelt' town but failing to assess the significance of cross-border ties or the relevance to their subjects of the mining region as a whole. It is only recently that the potential for insightful comparative analysis is again being fully realised. ${ }^{33}$

31 Jacques J. Maquet, 'Aspects Sociaux de L'Industrialisation a Elisabethville, Cycle d'Etude sur les Problems D'Urbanisation en Afrique', UNESCO conference, Addis Ababa, 25 April-5 May 1962.

32 Perrings, Black Mineworkers in Central Africa.

33 For a recent exception, see Enid Guene, 'Copper, Borders and Nation-Building: The Katangese Factor in Zambian Political and Economic History', African Studies Centre Leiden, African Studies Collection, 67 (2017). As well as the University of Oxford 'Comparing the Copperbelt' project, the WorkinMining project headed by Benjamin Rubbers is the most significant recent analysis of both Copperbelt regions: www.workinmining.ulg.ac.be (accessed 3 December 2019). See also the project on employment-tied housing in (post) colonial housing based at the University of Vienna, which includes case studies 
While new postcolonial leaders sought to integrate the two regions more fully into new nation-states, this was more easily said than done. The rulers of the Katangese secession (1960-3), a fundamental challenge to the unity of independent Congo, relied on relationships with their late colonial neighbours in the Central African Federation and funded the Northern Rhodesian African National Congress (NRANC). The resulting conflict led the new rulers of independent Zambia to see Katanga/Congo as a dangerous 'other', a negative lesson from which Zambia should differentiate itself. While the two mining regions followed parallel trajectories over the coming decades - partial and then full-scale nationalisation alongside growing political interference in company operations; the devastating effect of the downturn and sustained unprofitability of copper mining from the mid-1970s to the 2000s; falling formal employment and related social decline; and, in the late 1990s, corrupt privatisation and disastrous neo-liberal policies the meanings made by local societies about these changes contrasted sharply on either side of the border. While the resultant socio-economic grievances reinforced the Zambian Copperbelt's identity as a locus of political opposition and activism, in Haut-Katanga mineworking communities generally avoided the overt politicisation of their complaints and sought, as Benjamin Rubbers has shown, to express them in polite entreaties to a mine company most continued to regard as a caring parent that had temporarily abandoned them. ${ }^{34}$ This study seeks to explain why these similarities, alongside significant differences and divergences, are given such contrasting interpretations by Zambian and Katangese Copperbelt residents.

As noted above, processes of official and academic production of knowledge about African societies, although rooted in the structures and often serving the purposes of colonial capitalist domination, were in fact shaped or co-produced, in profoundly unequal circumstances, by a range of African intermediaries. ${ }^{35}$ In many significant studies of the role of anthropology and the wider social sciences in colonial Africa, the relationship between European researchers and African

of Zambia and Haut-Katanga: https://housing.univie.ac.at (accessed

3 December 2019).

34 Benjamin Rubbers, 'Claiming Workers' Rights in the Democratic Republic of Congo: The Case of the Collectif des Ex-agents de la Gécamines', Review of

African Political Economy, 37, 125 (2010), pp. 329-44.

35 Lawrance et al. (eds.), African Intermediaries. 
experts, chiefs and/or assistants is understood as central. ${ }^{36}$ For Northern Rhodesia, Lyn Schumaker in particular has demonstrated that the work and ideas of the RLI's African research assistants were vital to their findings. Schumaker's revealing exploration of RLI research processes, however, also shows the ways in which the mine communities under investigation, clearly recognising the political stakes of this work, were able to decide what was observed and, as a consequence, shape the findings that were reached. ${ }^{37}$ As Chapter 1 will elaborate, the RLI's tendency to focus research attention disproportionately on the most 'advanced' male African mineworkers was one that resulted from a shared desire by African researchers and influential African research subjects to present a particular view of their communities to the world. More generally, the increasing recognition that (largely) Western academic and official writing about African societies has been shaped in significant ways by those societies themselves, in ways that Western researchers were often unaware of, helps us appreciate that the boundary between elite and popular forms of knowledge about these societies is, like the Copperbelt border itself, one that was often permeable.

\section{Analysing the Intersection of Social History and Knowledge Production from Above and Below}

In his landmark study of Zambian Copperbelt society, Expectations of Modernity, James Ferguson discusses the challenge of comprehending, from an anthropological perspective, a community closely linked to the global economy and characterised by migration and a cosmopolitan culture. ${ }^{38}$ Many if not most Copperbelt residents understood their society as one in which socio-economic change, migration and cultural

36 Bruce Berman, 'Ethnography as Politics, Politics as Ethnography: Kenyatta, Malinowski, and the Making of Facing Mount Kenya', Canadian Journal of African Studies, 30, 3 (1996), pp. 13-44; Mwenda Ntarangwi, Mustafa Babiker and David Mills (eds.), African Anthropologies: History, Critique and Practice (London: Zed Books, 2006); Andrew Bank and Leslie J. Bank (eds.), Inside African Anthropology: Monica Wilson and her Interpreters (New York: Cambridge University Press, 2013).

37 Lyn Schumaker, Africanizing Anthropology: Fieldwork, Networks, and the Making of Cultural Knowledge in Central Africa (Durham, NC: Duke University Press, 2001).

38 Ferguson, Expectations of Modernity, passim. 
mixing were the norm. They were then, Ferguson found, adept at explaining social change, using local dialects of the language of urban modernity that dominated modernist social science and that was the subject of Ferguson's critique. My own experience, in periodic visits to the region from the early 1990s to the present day, has been similar: Zambian Copperbelt residents articulate both what they see as the underlying nature of their society and the ways it has been affected by recent changes in strikingly sociological ways. Theirs, they argue, is a modern and urban place in which development has created, among other things, multi-ethnic societies in which 'tribal' conflict is consequently unthinkable. Respondents stress the centrality of the money economy, of the ways that breadwinners carry financial responsibilities for their immediate families and wider kinship networks, and how these have changed over time. Comparisons between people, societies, areas and periods are commonly articulated in a way that consistently draws on a popular version of modernist discourse. As one typical example, here is interviewee Leonard Nkhuwa comparing two Zambian towns in the 1950s: 'Chipata was not well developed compared to Luanshya whose mines were developed with better infrastructure. Chipata relied on farmers so it was less developed'. ${ }^{39}$ In Haut-Katanga too, a variant on this discourse can be found when urban residents like Dieudonné Kalenga explain the appeal of artwork depicting village life as '[w]orks that evoked the reality of the traditional world; our ancestors ... life in our traditional society'. ${ }^{40}$

Copperbelt residents have had over decades longstanding and multiple contacts with researchers, whose ideas about the Copperbelt have been shaped by these residents and whose own perceptions have permeated local understandings of social reality. This is a community that has always explained itself to the wider world, representing itself in self-conscious ways that focus on its distinctive or novel character (relative to the rural societies from which most residents, their parents or grandparents migrated) and how this has evolved over time. This book will seek to demonstrate that the distinctiveness and novelty of Copperbelt urbanity was an idea that had both been articulated and internalised by Copperbelt residents

39 Interview, Leonard Nkhuwa, Mufulira, 17 July 2018.

40 Interview, Dieudonné Kalenga, Likasi, 8 June 2018. 
themselves, to help them make sense of their changing social reality and make claims - political, economic or cultural - about it.

The popular discourses of Copperbelt society about itself, fragmented and often undocumented as they have been, are clearly not one thing nor even a series of clearly distinct things, but it is possible to generalise about some of their most evident tropes. Communities and their leading actors have, from the start, represented them as modern spaces with values and practices distinct from the rural communities from which they or their families migrated. Living in the city required different ways of being, some of which - wage labour and new forms of family life - were prominent in the academic characterisation of Copperbelt society, but some of which - the hosting of rural kin and the necessity of conducting economic activities outside the mine, for example - were decidedly not. What it meant to live this new life, to claim a place for oneself, one's family or community, was understood in distinct ways by the diverse Copperbelt population. Ferguson's typological distinction between 'cosmopolitan' and 'localist' respondents is a useful starting point, but in practice both tendencies - for example, the celebration of the opportunities available in town alongside regret at the loss of reciprocal family life in the village - may be observed in the narration of one life history or in the lyrics of a single song. In this respect, mine labour might generate opportunities for advancement but equally involve exploitation and a loss of selfmastery. Becoming a UMHK-trained housewife could give women a respectable place in urban society, but equally tied one to a subordinate gendered role. Life outside the mine township as a marketeer or small businessperson was simultaneously risky and liberating. While some life experiences lead to a positive, Whiggish interpretation of historical change, more negative ones, both individually and collectively, create nostalgia for idealised boom times that were never the reality, at least for the majority of Copperbelt urbanites who lived outside the mine company system. Popular attitudes to the state, company, union, church, social class and ethnic identity, indeed to urban society as a whole, varied over time and between sections of that society in ways that, in a single history, can only be glimpsed.

Nonetheless, as befits a comparative analysis, strands of this popular articulation took related but distinctive forms in our two Copperbelt regions. As already noted, the specific meaning of and values associated with these new communities varied in Haut-Katanga and Zambia 
respectively, partly for the reasons outlined above. In Haut-Katanga the 'authoritarian paternalism' of UMHK/Gécamines seems to have influenced the relatively benign perspective of many cité residents: to generalise, they saw (and see) themselves as the beneficiaries of company largesse, but equally recognised that personal and/or familial progress through this system rested in the hands of ethnic intermediaries and was therefore partly dependent on patronage. In Zambia, while there is today nostalgia for the ' $Z C_{C C M}{ }^{41}$ model, the socio-economic progress of its communities was, it is believed, more the result of the actions of its residents, whether collectively in political or labour organisation, or individually, via hard work and sacrifice, than of company patronage and welfare. While many Zambian Copperbelt residents are bitter at the hand that economic fortune and/or political manipulation has dealt them, they reject the notion that ethnic favouritism or bias has been to blame, consistent with their culture of multiethnic workplace and community solidarity.

It is then tempting to ask the question, which came first: the social scientific representation of the 'modern' Copperbelt or the popular one? This is in any case a question that is impossible to answer but it is, in my view, not a useful starting point: African communities, like communities everywhere, have always articulated their history through origin stories that enable them to reflect on change over time, as a way of explaining their contemporary reality. The creation of such stories was not an equal or open process nor one that directly reflected social reality, since elites always sought to make claims in relation to these histories, whether to confirm or challenge the existing social order. It was rather a process that drew specific meanings from social reality and silenced others, but which itself changed over time in revealing ways. These everyday approaches to and techniques of identity formation and historically based claim-making travelled with migrants to the mining camps of the early twentieth century and were evidently at work in Africans' interactions with the Copperbelt social scientific post-World War Two boom. The social changes of that period were understood by social scientists and African societies alike as representing something 'new' and 'modern' relative to an essentialised rural past, a past that was marked by profound social disruption and change but

41 From 1982 the nationalised mine companies were brought into a single corporation, Zambia Consolidated Copper Mines (ZCCM). 
which was rendered static and stable in a colonial relationship to the dynamic present. $^{42}$

The RLI/CEPSI wave of social scientific writing and activity made available new technologies through which these societies could be represented. This enabled an expansion in the repertoire of claimmaking narratives of African communities. Labour unions, ethnic associations and political parties built on the evidence they gathered of African 'civilisation' and modernity to pursue their claims for economic or political advancement. This dynamic relationship between popular and official or academic representation has unfolded ever since, as Copperbelt communities have influenced and been represented in a palimpsest of ways by an ever-changing intellectual praxis and policy environment, whose only consistency is the comparison of the changing present and the stable past, in which, however, the specific content of 'past' and 'present' and the temporal boundary between them is ever shifting. For example, as the period of 'decline' (Chapter 8) has extended - notwithstanding brief booms and jobless recoveries - to the present day, the nostalgic recall of the modernist urban 'belle époque' (once a period of disruptive change, now a halcyon of social stability) has sharpened and extended backwards to encompass the lived experience of all but the oldest Copperbelt residents, with decline generally associated only with the period since mine privatisation in the late 1990s. This is despite clear evidence, in archives and earlier studies, that a real and sustained economic decline set in from the late 1970s and had come to directly affect living standards by the 1980s. Likewise, the widely identified disruptive effects of post-privatisation social change on generational relations, explicitly compared with a supposedly stable and cohesive past, ignores overwhelming evidence of enduring anxiety about juvenile crime and/ or delinquency, identified by successive Copperbelt observers and residents as a 'new' and worrying phenomenon in the 1950s, 1970s and 1990s alike. Drawing attention to such inconsistencies between memory and contemporaneous evidence identifies the performative and selfconscious nature of popular historical claim-making, but the aim in

42 The characterisation by social scientists of rural or 'traditional' African society as existing in a 'timeless' or 'past' relationship to a normative Western/ modern present was first elaborated by the leading ethnographer of urban Katanga, Johannes Fabian, Time and the Other: How Anthropology Makes Its Object (New York: Columbia University Press, 2014 [1983]). 
doing so is both to address where they obviously deviate from or obscure wider social realities and to draw attention to their ubiquity, central as they have always been in making sense of life in a permanently precarious urban society.

Through such an approach, this analysis seeks to unlock a central problem of writing social history in an era of post-colonialism and post-modernist thought. For much of the twentieth century, historians and social scientists saw society as an essentially material reality that could be measured, observed and recorded: innovative methodologies, for example quantitative data collection and later interviews and oral testimony, were developed to overcome the limits of state archives, but it was generally assumed that it was both possible and necessary to capture a close approximation of social reality. Many historians of African mining in general and of the Copperbelt in particular built on these assumptions to produce important studies that nonetheless depended largely on the archive to tell mine history through the prism of capital-labour relations. ${ }^{43}$

Since the 1970s post-modern turn and in particular the seminal influence of Said's 'Orientalism', historians of the global South have become acutely aware of the ways in which the production of knowledge by imperial actors about non-Western societies played a central role in justifying and shaping colonial projects. ${ }^{44}$ The centrality to colonialism in Africa of information gathering and production,

43 Harold Wolpe, 'Capitalism and Cheap Labour-Power in South Africa: From Segregation to Apartheid', Economy and Society, 1, 4 (1972), pp. 425-56; Charles Van Onselen, 'Worker Consciousness in Black Miners: Southern Rhodesia, 1900-1920', Journal of African History, 14, 2 (1973), pp. 237-55; Bill Freund, Capital and Labour in the Nigerian Tin Mines (Harlow, UK: Longman, 1981). For the Copperbelt see, for example, Higginson, A WorkingClass in the Making; Patrick Harries-Jones, Freedom and Labour: Mobilization and Political Control on the Zambian Copperbelt (Oxford: Basil Blackwell, 1975 ) and Elena Berger, Labour, Race and Colonial Rule: The Copperbelt from 1924 to Independence (Oxford: Oxford University Press, 1974).

Edward Said, Orientalism (London: Pantheon, 1978). Among the most relevant works influenced by Said are Dipesh Chakrabarthy, Provincializing Europe: Postcolonial Thought and Historical Difference (Princeton, NJ: Princeton University Press, 2000) and Partha Chatterjee, The Nation and Its Fragments: Colonial and Postcolonial Histories (Princeton, NJ: Princeton University Press, 1993). For Africa, see the work of Valentin Y. Mudimbe, most notably The Invention of Africa: Gnosis, Philosophy and the Order of Knowledge

(Bloomington: Indiana University Press, 1988) and Achille Mbembe, especially On the Postcolony (Berkeley: University of California Press, 2001). 
classification and research has been well established, as has its consequences for how researchers should approach the official archive (for which also see below). ${ }^{45}$

For the Copperbelt, the work of Ferguson and - for Haut-Katanga Benjamin Rubbers have contributed hugely to our understanding of how knowledge production around the question of African 'adaptation' to 'modern' society played an important role in both social change and in academic presentations of the region. Meanwhile the 'cultural turn' focussed attention on the lives of mineworkers outside the workplace, encompassing their ongoing connections to rural areas of origin and their familial and spiritual lives. ${ }^{46}$ In this regard, one of the most important urban social history projects carried out anywhere in Africa is the 'Mémoires de Lubumbashi' project, led by Donatien Dibwe dia Mwembu and Bogumil Jewsiewicki and based at the University of Lubumbashi. This pioneering project consciously transgresses the conventional divide between academic research (e.g. oral histories) and popular culture in its characterisation of popular theatre, painting and music as representing valid histories of the city. It has brought together university historians, artists and musicians, and members of Lubumbashi's diverse society in events, workshops and performances that emphasise the co-creation of historical understandings and discourses. $^{47}$

More generally, however, the limitations of post-colonial approaches, identified by many observers, are certainly relevant here: there is in them a tendency to shift attention away from marginalised

45 Helen Tilley, Africa as a Living Laboratory: Empire, Development, and the Problem of Scientific Knowledge, 1870-1950 (Chicago, IL: University of Chicago Press, 2011); Ann Laura Stoler, Along the Archival Grain: Epistemic Anxieties and Colonial Common Sense (Princeton, NJ: Princeton University Press, 2008).

46 Patrick Harries, Work, Culture and Identity: Migrant Laborers in Mozambique and South Africa, c.1860-1910 (Portsmouth, NH: Heinemann, 1994); Carolyn Brown, 'We Were All Slaves': African Miners, Culture, and Resistance at the Enugu Government Colliery (Portsmouth, NH: Heinemann, 2003).

47 Donatien Dibwe dia Mwembu and Bogumil Jewsiewicki, Le Travail Hier et Aujourd'hui: Mémoires de Lubumbashi (Paris: L'Harmattan, 2004);

Donatien Dibwe dia Mwembu, 'Historical Knowledge Production at the University of Lubumbashi (1956-2018)', in Miles Larmer, Enid Guene, Benoît Henriet, Iva Peša and Rachel Taylor (eds.), Across the Copperbelt: Urban and Social Change in Central Africa's Borderland Communities (Oxford: James Currey, 2021), pp. 296-320. 
societies themselves and towards the producers of knowledge, privileging their place in the historical record even while criticising their views and impact. They also tend to create a division between an evidently artificial distorted imperial history, shown to be implicitly or explicitly false, and an intrinsically authentic subaltern social reality that, whether documented or not, is still out there waiting to be discovered. If, however, we appreciate that knowledge production, in its various forms, is the way that communities make sense of and advance claims in relation to social history, that it is social history, then we can potentially overcome these problems. This is to deny neither the realities of material injustice and exploitation, nor the distortions resulting from Western-dominated forms of knowledge production, whether generally or in the specific example of Copperbelt society. It is, however, argued that in historicising the meanings attributed to those realities by both intellectual observers and African residents of the Central African Copperbelt, documenting how they have changed over time and identifying the occasional interactions between these structurally unequal but nonetheless equally energetic producers of knowledge about these societies, we may better appreciate the ways in which historical meaning comes to be attributed to social reality.

It should, however, be stressed that this study does not generally seek to reconstruct the specific instances when academic researchers and African community 'met' and exchanged ideas about Copperbelt society. While a number of such direct encounters are noted, for example Hugh Tracey's 'discovery' of popular musicians and Johannes Fabian's sustained engagement with Katangese painters and theatrical performers (Chapter 7), there are equally instances where elite and popular knowledge production about specific topics, most strikingly gender relations (Chapter 5), while touching on parallel themes, reached deafeningly distinct conclusions. Indeed, the vast majority of academic, governmental and non-governmental researchers, having engaged with Copperbelt communities in diverse ways while gathering knowledge, tended to disseminate that knowledge only to their Western (and later African) academic colleagues, governments and other elite audiences, doing little or nothing to make it available to the communities that were vital to its production. Awareness of these bodies of knowledge certainly leaked out to Copperbelt actors and were taken up opportunistically to reinforce identities and to advance claims, but it is impossible to capture in all instances the exact ways in which 
that occurred. The aim here is then to capture and historicise the intellectual ecosystem in which ideas about the Copperbelt circulated and changed, reflecting and influencing societal change in doing so, rather than to 'track and trace' the myriad specific examples of ideational transmission.

Nor does this study pretend to be a fully realised intellectual history of the multiple elite producers of knowledge whose works are discussed. While insightful research on, most particularly, the RLI and CEPSI researchers (by Schumaker and Poncelet and Rubbers respectively) has demonstrated the influence of personal background, academic training and political orientation on their findings, the breadth and range of the analytical framework means that to produce an equivalent analysis of the intellectual influences of the dozens of academic and policy-oriented researchers cited herein would be well beyond the bounds of a single-volume history and certainly the capabilities of its author. Instead, the aim is to shift the centre of intellectual history from its privileged and (usually) Western perspective to its field of production, so as to analyse successive intellectual historical contexts within which both popular and elite knowledge production took place, and that knowledge itself. This approach, influenced by the 'Mémoires de Lubumbashi' project but taking a very different direction, intentionally collapses the conventional barrier separating the producers of knowledge from the subjects of it: as a result, many of the academics whose works are analysed in this study are both cited in regard to the research they have carried out and situated as actors in the history of knowledge production about the region.

\section{Sedimentation in Historical Writing: Structure, Methodology and Sources}

In order to reflect this interaction between social history and knowledge production, this book is organised into a structure that is at once tightly thematic and loosely chronological. Each chapter focusses on a specific discourse of representation of 'the Copperbelt' that emerged at a particular time in the region's history and that was, for a time, relatively important or even hegemonic, both in the historical and/or social scientific study of it and - in different ways - in the popular imagination.

This way of ordering the book is not, however, designed to suggest that one intellectual paradigm was simply replaced by its successor. 
Writing about mining societies presents the obvious but nonetheless irresistible analogy of geological time for our understanding of historical change. ${ }^{48}$ Historical and historiographical change, like geological sedimentation, lays down layers of understanding and representation that, though partly buried beneath successive layers in turn, may still be accessed by later generations, whose perspective and positionality towards each successive form of historical representation has itself been ineluctably changed by the new layers on which they and their social reality now stand. Analogous to this, Patience Mususa shows how technological innovation revalued Copperbelt 'waste', in the form of the dumps of processed rock scattered across the Copperbelt landscape, and in doing so created opportunities for new forms of precarious and gendered labour whose meaning and legitimacy depended on its shifting economic value. ${ }^{49}$ Just as technological innovations enabled the re-evaluation of the value of the mining past, so changes to social reality, which are always a globally connected process in the Copperbelt, can lead marginalised elements of that past of hitherto little value in claim-making to be brought to the fore. The only consistent factor in this ever-shifting landscape of contemporary memory is historical claim-making of one kind or another, rooted in the relationship between present and past but always emphasising some aspects of historical experience while silencing others.

A revealing example is environmental damage or pollution: as Chapter 9 shows, the emission of sulphur dioxide and other 'waste' from copper mining and smelting activities into adjacent Copperbelt communities affected the health and well-being of residents from the start. Unlike workplace health however, which was the subject of ILO conventions and state and mine company regulation, it attracted little international attention. Mine companies successfully 'offshored' the issue and thereby successfully avoided responsibility for its effects. It likewise remained a subject absent from both academic research and

48 A related (and brilliant) use of the 'sedimentation' concept can be found in Thomas Bierschenk, 'Sedimentation, Fragmentation and Normative DoubleBinds in (West) African Public Services', in Thomas Bierschenk and Jean-Pierre Olivier de Sardan (eds.), States at Work: Dynamics of African Bureaucracies (Leiden: Brill, 2014), pp. 221-45.

49 Patience Mususa, 'Contesting Illegality: Women in the Informal Copper Business', in Alastair Fraser and Miles Larmer (eds.), Zambia, Mining, and Neoliberalism: Boom and Bust on the Globalized Copperbelt (New York: Palgrave Macmillan, 2010), pp. 185-208. 
significant policy or political attention. For Copperbelt residents, 'senta' or 'kachoma' (sulphur dioxide pollution) was an everyday hazard that damaged crops and affected Copperbelt communities in unequal ways. But if it led to grumbling and even discontent, it did not generate overt protests or find its way into the minutes of community or union meetings. This was until the late 1980s, when extractive pollution - the subject of concern in Western countries for some decades - came, in the context of mine privatisation, to be expressed in the form of Environmental Impact Assessments (EIAs). Environmental NGOs and local campaigners raised awareness of the hazards of mine activities and, on the ground, Copperbelt communities articulated their concerns regarding pollution, not only in relation to contemporary mining but also the past: who would pay for damage inflicted by earlier companies and political regimes? While there is a clear realisation that the ill-effects of mine activity on Copperbelt communities has an extensive history, interviews focussed on the past reveal a general silence about pollution as a historical concern: it is, instead, an issue of today, whose ambiguous and even contradictory relationship to the recently buried past is still being unearthed.

This example suggests that, for any particular set of actors at a specific time, a historical framework of understanding may suddenly be 'uncovered' and revalued as the basis of claim-making, for reasons that can be explained in reference to its particular circumstances. An important example is the politicisation of ethnic difference in HautKatanga. Locally this found expression in articulation of the competition between 'autochthons' and 'outsiders' in the political violence of the early 1960s and again in the early 1990s. As will be explained in Chapter 4, in the early 1960s Katangese secessionists sought to resist the growing political authority of Kasaian migrants to mining towns by constructing a Katangese 'national' identity rooted in a reading of a pre-colonial past in which powerful kingdoms generated wealth and authority, partly by means of copper mining. ${ }^{50}$ The exclusionary nature of this nationalist discourse underwrote the secession and fuelled the repression of Kasaian residents of Katanga's mining towns. For decades after, such tensions in Haut-Katanga's mining towns were largely quiescent: while ethnic associational activity was

50 Miles Larmer and Erik Kennes, 'Rethinking the Katangese Secession', Journal of Imperial and Commonwealth History, 42, 4 (2014), pp. 741-61. 
central to social belonging in urban Katanga, it was largely delegitimised as an overt form of politicking in Mobutu's Zaire. ${ }^{51}$ In the early 1990s however, as Mobutu's regime faced growing political opposition, this buried seam of autochthonous sentiment was deliberately excavated as the basis of a local political movement that led to the killing of c.5,000 'Kasaians' (many born in Katanga) and the displacement of around one million from towns including Kolwezi and Likasi. ${ }^{52}$ Ethnic violence of this scale has never occurred in the Zambian Copperbelt and, from the perspective of most of our respondents, is unthinkable. It is clear, however, that earlier waves of more limited political violence - that between the United National Independence Party (UNIP) and the African National Congress (NRANC) in the early 1960s for example, and between UNIP and the United Progressive Party (UPP) a decade later - involved ethnically based mobilisation that was, however, downplayed in an official politics wherein accusing one's opponents of 'tribalism' was more powerful than openly deploying it oneself. This did not reflect anything structurally distinct in the Zambian Copperbelt's political economy but rather the legitimising nature of an anti-ethnic discourse among its self-consciously cosmopolitan populace, one that has existed uneasily alongside the more covert use of 'tribalist' discourse in political life.

As befits the history of a region that, alongside its own local dynamics, has been constructed in regional, national, continental and global terms, this study utilises a wide range of analytical scales. The focus is at times on the global economy, from the post-World War Two positioning of the Copperbelt as a region of industrial modernity in the African 'bush' to an ailing patient in need of urgent treatment in the 1980s. The ambiguous relationship of both regions to their respective

51 The 'de-ethnicisation' of Zairian politics is discussed in detail in Crawford Young and Thomas Turner, The Rise and Decline of the Zairian State (Madison: University of Wisconsin Press, 1985), pp. 149-57.

52 International Crisis Group, Katanga: The Congo's Forgotten Crisis (Nairobi/ Brussels: International Crisis Group, 2006), p. 1; Sandrine Vinckel, 'Violence and Everyday Interactions Between Katangese and Kasaians: Memory and Elections in Two Katanga Cities', Africa, 85, 1 (2015), pp. 78-102; Donatien Dibwe dia Mwembu, 'État de la question sur le conflit Katangais-Kasaïen dans la province du Katanga (1990-1994)', in B. Jewsiewicki and Leonard N'Sanda Buleli (eds.), Constructions, Négociations et Dérives des Identités Régionales dans les États des Grands Lacs Africains: Approche Comparative (Laval: Université Laval, 2005), pp. 9-48. 
colonial states and nation-states - as the key generator of wealth for their development and (as a result of that wealth) as a politically powerful region requiring more effective integration - is an equally important frame of analysis. In considering the Central African Copperbelt as a single region, the approach is simultaneously holistic and comparative: the study aims to show what was true for the region as a whole; how differences between the two parts of the region developed and were maintained in a process of social and ideational change; and how the cross-border perception of the two regions shaped the mutual understanding of each other. At times the analysis shifts to a sustained focus on the specific experience of either the Zambian or Katangese Copperbelt, the better to grasp the noteworthy differences in their history alongside their parallel trajectories. Finally, the focus is at times on the specific experience of residents of Mufulira and Likasi, two mining towns in Zambia and DRC respectively, in which intensive research and interviews have been carried out so as to enable consideration of the ways they have experienced both social change and changing ideas about Copperbelt society.

If we recognise that all existing social scientific and historical analysis of the region has been inextricably shaped by the context in which it has been produced, then it becomes vital, while making use of that analysis, to simultaneously place it in its own historical and intellectual context. This evidently applies to the modernist literature of the $1950 \mathrm{~s}$ and early 1960s and in this regard the study builds on Ferguson's seminal analysis of RLI scholarship. It, however, extends this approach to encompass scholarship on Haut-Katanga and to cover a much longer period. This includes the decline of recent decades in which, not coincidentally, post-modernist scholarship including that of Ferguson has resonated with the experience and perception of crisis, a perception that both reflects a real decline in living standards but also a modernist nostalgia for a golden age that exists more in historical memory than historical experience.

Archival evidence about the Central African Copperbelt must equally be understood as reflective of the context in which it was produced, to be read both 'with' and 'against' the grain and interpreted as a form of knowledge production. The region is comparatively wellendowed with records: unsurprisingly, mine companies produced vast swathes of paperwork documenting their activities for investors, political authorities and their own officials. These have been assiduously 
archived for the colonial period and, to a lesser extent, the decades since political independence: the ZCCM-IH archives in Ndola are a particularly impressive repository, while the UMHK archives in Brussels are equally important if less extensive. The Gécamines period is, however, less well archived and considerable effort has gone in to accessing those company records that are still available, in Belgium but also Lubumbashi and Likasi. Governmental records for Northern Rhodesia/Zambia and Belgian Congo/Haut-Katanga follow a similar pattern, with few relevant materials available for the period after the declaration of the Zambian one-party state in 1972 and equally during Mobutu's rule of Congo/Zaire from 1965. One exception is the UNIP archives, the records of the former Zambian ruling party that, thanks to the efforts of dedicated researchers and the British Library Endangered Archives programme, are now available to researchers online. ${ }^{53}$ A similarly welcome process is now underway for the records of the Mineworkers' Union of Zambia (MUZ). A range of other written records, from those of the IMF and World Bank in Washington, DC to the Mufulira town council, are also utilised. All these archives are of course skewed in their foci and analytical frameworks in exactly the ways that are critiqued here and elsewhere: towards the site of mine production, the male mineworker and the formal organisation of labour, state and capital. These archives must therefore be equally read for their lacunae and distortions as much as for their assiduous record-keeping on certain subjects: in this regard company archives are particularly revealing for the way that mineworkers' wives, a central target of corporate intervention (Chapter 5), are nonetheless virtually absent from the record as historical subjects.

The logical next step in accessing such 'hidden' experiences for the historian of Africa is of course the oral history or interview. Such interviews certainly have the capability of reading in the experiences and perceptions of marginalised groups and of challenging established perspectives. They are themselves an important part of the fabric of Copperbelt historiography and have been used by generations of researchers whose work is in part the subject of this study. As well as dozens of interviews with specific actors in Copperbelt society, from social welfare officers to musicians and visual artists, the

53 British Library Endangered Archives Project, UNIP archives: https://eap.bl.uk/ project/EAP121/search (accessed 3 December 2019). 
analysis makes use of $c .110$ extended interviews with long-term residents of both Mufulira and Likasi carried out in 2018, together with other interviews conducted by members of the 'Comparing the Copperbelt' research team between 2017 and 2019. The majority of these, conducted in a combination of Kiswahili, CiBemba, French, English and other languages, made use of a fixed set of open-ended questions to elucidate interviewees' understanding of their lived experiences and of the historical changes they had witnessed (see the References section). While in no way a representative sample of Copperbelt demographics today or in the past, these interviewees included roughly equal numbers of women and men, those who made their living within and outside the mining complex, and from a wide range of economic, educational and ethnic backgrounds. Where an interviewee's specific work or life experience is relevant to the issue on which they are cited in this text, this is elaborated on there, but otherwise interviewees are cited as commenting on their own experience or understanding.

Given the wider analytical framework of this study, it will be evident that these interviews were not treated as providing self-evident truths about the nature of Copperbelt social history, nor are they consciously counterposed to the official archive or to academic studies in any systematic way. Interviewees are assumed to be influenced by the historical context in which they have lived and the forms of knowledge about it to which they had access and which indirectly framed their experience. Interviews are therefore regarded as performative events in which our interviewees - like their predecessors over sixty or more years of such research - articulated their understanding of the region's history in relation to their personal experience, their perception of interviewers' intentions and background, and the potential of the interview process to advance their own circumstances. In this text, selective use is therefore made of interview material that sheds light on the social history of the Central African Copperbelt, but attention is also drawn to the ways in which the emphases and ellipses in interviewee narratives both reflect the history of knowledge production in the region and seek to shape that knowledge in this, the latest iteration of it.

Clearly the most challenging aspect of any study of this type is to gain access to the contemporaneous perception and articulation of lived experience in the period under study. Capturing the precise 
moments in which popular and elite knowledge about Copperbelt societies coalesced, conversed with and/or confronted each other is not a realistic aim. This volume instead seeks to place forms of popular texts - the publications and pamphlets of political activists, the speeches of union officials and the song lyrics of musicians, among others - in comparative conversation with academic and official discourse about the nature of historical change in Copperbelt society. Following the argument outlined above, these popular texts are not presented as a more authentic understanding of these processes than official discourses but should rather be understood as performative characterisations of historical change that underpin claims about the relationship between past, present and future. Nonetheless, it may be observed that, while elite knowledge production has tended to essentialise the binary discussed above - between a traditional, rural and stable past and a modernising, dynamic urban present - popular knowledge has commonly engaged with that same binary in more creative, even playful, ways that shed particular light on the ways in which historical change is perceived and acted upon.

Finally, given the evident fact that this study is only the latest in a long history of knowledge production processes conducted by Western scholars on and about Copperbelt societies, its own positionality and limitations should already be clear but must be explicitly acknowledged. The knowledge produced here certainly relies on the (male, white European) author's engagement with African-authored scholarship that has decisively shaped his own understanding of Copperbelt society, and with dozens if not hundreds of local interlocutors, intermediaries and influencers from that society, a few of whom are mentioned in the Acknowledgements. Much of the labour that went into this volume was that of African researchers who, in a more equal world, would be the authors of their own studies of Copperbelt society, and whose initiatives and ideas have decisively shaped this volume and the wider outputs of the 'Comparing the Copperbelt' project. ${ }^{54}$ While some scholars and activists argue that the resultant works of knowledge such as this one should reflect this labour by naming each such worker as a co-author of resultant publications, my own approach is to

54 For all project outputs, see https://copperbelt.history.ox.ac.uk (accessed 3 December 2019). 


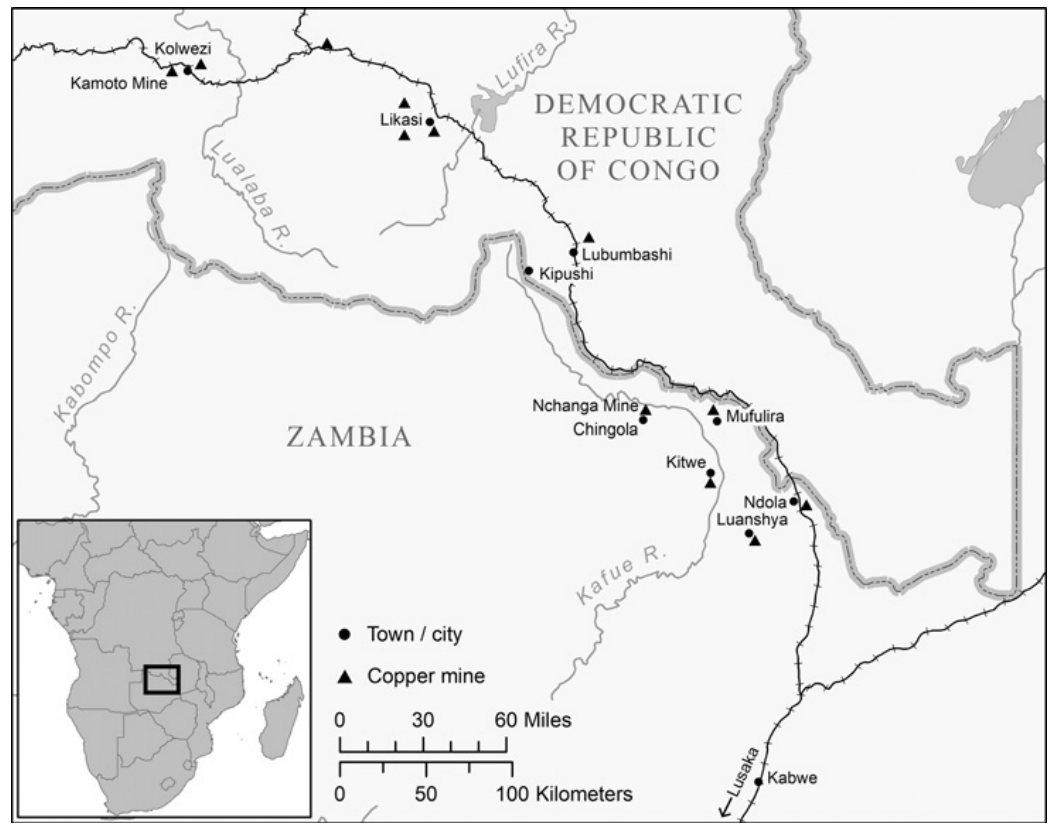

Figure 0.1 Map of the Copperbelt region. Rachel Taylor. First published in M. Larmer, E. Guene, B. Henriet, I. Peša, R. Taylor (eds.), Across the Copperbelt: Urban and Social Change in Central Africa's Borderland Communities (Oxford: James Currey, 2021).

treat this published text as the outcome of my personal and undeniably privileged reflections on Copperbelt social history, for which no one is responsible but myself. In this way the aim is to lay bare the continuing inequalities in academic knowledge production about African societies, as a very modest contribution to overcoming them. 